\title{
Emotional Management among the Headmaster of Intermediate Schools
}

\author{
${ }^{1}$ Muntaha Mutashar AbdulSahib and ${ }^{1}$ Wasan Nasir Muhamad \\ \{Dr.muntaha1@yahoo.com\} \\ ${ }^{1}$ Department of Physics, College of Education for Pure Science- Ibn Al-Haitham, University of \\ Baghdad, Iraq
}

\begin{abstract}
The research aims to identify the level of emotion management among middle school principals. It also aims to know the differences in the level of emotion management among middle school principals according to the type variables (males and females) and years of service (years - 5 years) and ( 5 and above). The research has determined the middle school principals (boys, girls) in the third Rusafa Education Directorate in Baghdad for the academic year (2019-2020). A sample of schools was taken from this community, which amounted to (190) schools, distributed in (95) male schools and (95) schools. The researcher adopted the emotions management scale prepared by (Ghada Faisal) (2013), and the results indicated that the research sample can manage emotions higher than the hypothetical average of the scale. And the presence of differences in the management of emotions according to the gender variable in favor of males and according to the variable of years of service for the benefit of managers who have more than five years of service. In light of these results, the researcher developed several recommendations.
\end{abstract}

Keywords: emotion management, middle school, Education Directorate

\section{Introduction}

\subsection{The problem}

Any individual who faces problems that represent an obstacle to achieving his goals, which he needs to deal with and find a solution to and this requires an ability to manage emotions. The school management profession is a profession that is not without difficulties, as it requires a person who is able to manage his emotions and control them in a skilled and professional manner, especially in middle schools, since the principal deals with an age group at a critical stage which is adolescence. Most psychologists emphasize the need to organize, evaluate and manage emotion, and use appropriate strategies to deal with or adapt to stresses in the environment surrounding the individual in order to maintain the integrity of the character (Lazaurs, 1981,52).

The conditions in which the Iraqi people went through wars, destruction and killing have generated a lot of unstable psychological status and this is what we see through daily coexistence in social life and it is assumed that the person has psychological strength and ability to emotional discharge and the management of emotions for healthy coexistence, which It imposes a research problem that 
needs to be researched, so this research came to know the level of emotions management among middle school principals, to get to know the reality of school administrations, as they are an important segment of responsibility for dealing with students with individual problems and that they are role models for students, so it must be Their psychological state A healthy machine, while the circumstances around them impose psychological pressure on them.

\subsection{The Research Methodology:}

An important aspect in the life of individuals and determining the personality style is emotional management, as individuals who have the ability to manage emotions have the ability to achieve psychological balance and postpone the satisfaction of needs (Tarannum \& Khatoon, 2009,117).

Many individuals try to organize feelings and emotions positively as a way to manage their emotions, and this has a major impact on physical and mental health, social relations and work completion, and conversely, people who do not have the ability to manage emotions are subject to psychological disorders such as fear, depression and anxiety, And physical illnesses such as headache, fatigue and other diseases ((Birmingham, 2001, 123).

Managing emotions help the individual to make decisions in the various circumstances they face, and it also serves as a major process in controlling oneself. Whenever the individual is able to manage his emotions, he has sufficient ability to make the right decisions (Al-Adl, 1995, 125).

The principal of the school is an important element in the educational process. Through it is his responsibility to manage the school with all its belongings and members, and he is the first and last responsible for them and for solving, students 'problems and helping them to overcome the problems they go through during the course of the educational process, so it must be They have the ability to manage their emotions before managing the emotions of others.

Hence the importance of the current research and the importance of the research variable, as no study has been found in the previous psychological literature on emotional management among middle school principals (according to the two researchers' knowledge).

It also highlights the importance of research in the research community, who are the school principals who constitute an effective element in the educational and educational process, as it has not been studied, as this research will provide us with statistical indicators for them. In particular middle school principals.

\subsection{Research objectives:}

Targeted search identifies:

1. The level of emotion management among middle school principals.

2. Differences in the level of emotion management among middle school principals, according to the gender variable (male, female)

3. Differences in the level of emotion management among middle school principals, according to the variable of years of service (one year - 5 years) and (5 or more).

\subsection{Research Constraints:}


The research is determined by middle school principals (boys and girls) at the third Rusafa Education Directorate in Baghdad, for the academic year (2019-2020).

\subsection{Definition of Terms:}

Agitation management: It was defined by John in 1995 'The individual's ability to express his emotions so that he is aware of the nature of his emotions and the goals that he seeks to achieve so that emotions affect positively his decisions' (John, 1995, 45).

Mayer and Salovey in 2001 'The ability to understand feelings and self-emotions, to open up feelings to others and share them with these feelings, which leads to emotional equilibrium' (Mayer \& Salovey, 2001, P.433).

Theoretical definition: The definition of (Meyer and Salovey) will be adopted as a theoretical definition in this paper.

The procedure definition is: (The total score obtained by the school principal from his answer to the paragraphs of the Emotional Management Scale used in this research).

\section{Theoretical framework and previous studies}

\subsection{First: Theoretical framework:}

Mayer \& Salovey Theory (1990) took a great interest in intelligence, especially in the non-cognitive aspects, and their motivation for developing their theory of emotion management was one of the components of emotional intelligence. Their theory differs from Bar-On theory in terms of component analysis and the preparation of measuring tools for these components. It differs from other measures that measure emotion management on the basis that it is a feature (Baron, 1998, P.209). Myers and Salovey suggest four components of Emotional Intelligence:

1- Realize emotions

2- Understanding emotions

3- Flexibility (Passive Facilitation)

4- Emotional equilibrium

They affirm that emotions relate to the internal relationships of the psychological system of the individual, as well as external relations related to other people and external stimuli, when a person's relationship changes with other people or with things, his emotions towards them or about something change, and a sense of fear begins from The person who becomes a threat to him. These relations are accompanied by real or imagined signs and expressions that arise over them, which are emotions. Knowing the meanings of emotions, their relationship and trying to control them, enables the individual to solve his problems with a mental methodology and regular health steps (Salovey \& Mayeres, 2002, P.261-263).

Myers and Salovey emphasized that the ability to control and evaluate emotions include the ability to identify emotions in physical situations, and to determine the emotions of others, through the individual's skills, behavior, and appearance, as it helps in solving the problems experienced by him, and understanding complex feelings, and interrelated feelings Like dread, sudden fear (Hein, 2001, P.57). 


\subsection{Second: Previous studies:}

What the two researchers obtained from previous studies related to the research will be presented as follows:

A- Ali Hassan Al-Mamouri Study (2008):

I aimed to know the relationship between emotion management, polarization of expression and patterns of thinking. The study sample included (200) university professors, the T-test for one sample and the T-test for two independent samples were used, and the Pearson Correlation Coefficient / and the tests were prepared by the researcher. The results indicated that the association between emotional management and scientific thinking is higher compared to the rest of the thinking pattern.

\section{B- Ghada Faisal Hussein's Study (2012):}

The study aimed to know the relationship between emotion management and some variables among female physical education teachers and other material teachers. The sample of the study included (335) schools, from the governorate of Baghdad. Statistical methods such as (T-test for one sample, T-test for two independent samples) were used, and the researcher built the emotion management scale. The researchers reached the results that indicate that physical education teachers are better than other teachers in emotion management and that older female teachers are better in managing emotions.

\section{C- Study of Abdulaziz Al-Musawi and Sarah Thamer:}

The study aimed to identify the management of emotions among university students. Her sample reached (400) male and female students. Statistical methods were used by (T-test for one sample, T-test for two independent samples, and the study reached the results that confirm that the research sample has a high level of emotion management and there are no differences in the management of emotions according to the variables of type, specialization and grade.

\subsubsection{Balancing between previous studies:}

From looking at the previous studies that were reviewed, we find that their goals are different, in addition to the variation of their samples also in terms of size and nature of the sample, which is also different from this sample of our research that included middle school principals, and used all T-test for one sample and T-test for two samples as independent of our research. The samples of these studies had a high level of agitation management. The results of our research will be compared with these studies in the results presentation chapter.

\section{Research procedures method}

\subsection{Research Methodology:}

The descriptive approach relied upon, as it is the most appropriate approach to study the phenomenon or reality as it is in reality, and described it accurately and quantitatively and qualitatively, a failure to reveal the differences between the variables.

\subsection{The research community and its sample:}

The research community included middle school principals in the third Rusafa Education Directorate. A sample of schools was taken from this community, amounting to (190) schools 
distributed to (95) male schools and (95) female schools for the academic year (2019-2020) meaning that (190) school principals were taken. Table (1) clarifies this.

Table (1) The research sample is divided according to type
\begin{tabular}{|c|c|c|}
\hline Total & \multicolumn{2}{|c|}{ Type } \\
\cline { 2 - 3 } & Female & Male \\
\hline 190 & 95 & 95 \\
\hline
\end{tabular}

\subsection{Research tools:}

This includes the following:

Agitation Management Scale: The two researchers adopted the emotions management scale prepared by (Ghada Faisal) in (2013). This scale consists of (63) paragraphs, five alternatives are placed before each paragraph (they apply to always, apply to a lot, apply to sometimes, apply to a little, do not apply at all), and the correction is given by giving grades $(1,2,3(4,5)$ for positive paragraphs, whereas negative paragraphs are given grades $(5,4,3,2,1)$, and the score is calculated for each respondent by adding the grades on the scale paragraphs, and the highest score that the respondent can obtain is (315). The lowest degree is (63), with a hypothetical average of (189).

And validity and reliability of the tool extract, this consists of:

A. Honesty: To verify the apparent sincerity of the scale, it was presented to a group of arbitrators and experts in psychology, measurement, and evaluation to verify its validity. The scale obtained the approval of most arbitrators and experts, and all paragraphs, with a percentage of more than $(80 \%)$, as the percentage was adopted as a standard To accept the clause, the clause approved by $(80 \%)$ of the arbitrators or more is considered acceptable and remains within the scale.

B. Stability: The stability of the scale was extracted by the method of testing and re-testing, as the scale was applied, and then re-applied over a time period of (21) days, after which the Pearson correlation coefficient was used to find out the relationship between the degrees of the first and second applications, as the value of the correlation coefficient of stability. The value of the stability coefficient of the agitation management scale $(0,80)$, which are the values of the stability coefficient acceptable according to what was mentioned in previous studies.

\subsection{Final application:}

After the two researchers completed the validity and consistency measures of the scale, the emotions management scale was applied to the research sample of (190) principals in middle schools in Baghdad Governorate, and the application period lasted for a period of (40) days.

\subsection{Statistical means:}

The two researchers extracted the results using the following statistical methods:

1. T-Test for two independent samples: to know the significance of the difference in the management of emotions according to the type variables and years of service. 
2. T-Test for one sample: to know the significance of the difference between the sample mean and the hypothetical mean on the scale of emotion management.

\section{Research results and discussion}

\subsection{First: Search results:}

\subsubsection{The first goal: to identify the level of emotion management among middle school} principals.

The results of the research showed that the mean of the scores of middle school principals on the scale of emotion management has reached (212) and the standard deviation (15.15) and the hypothetical average of the scale (189) was that using the T-test for one sample, it appeared that the calculated T value had reached (0.079) at the level of (0.05) and the degree of freedom (189) which is smaller than the tabular $\mathrm{T}$ value of (1.96), and this indicates that the research sample has the ability to manage emotions higher than the hypothetical mean of the scale. Table (2) illustrates this:

Table (2) Arithmetic circles, standard deviations, and T-values for the emotional management

\begin{tabular}{|r|r|r|r|r|r|r|}
\hline $\begin{array}{r}\text { Indication, } \\
\text { level (0.05) }\end{array}$ & \multicolumn{2}{|r|}{ T Value } & $\begin{array}{r}\text { Hypothetical } \\
\text { average }\end{array}$ & $\begin{array}{r}\text { Standard } \\
\text { deviation }\end{array}$ & Average & Sample \\
\cline { 2 - 3 } & $\begin{array}{r}\text { Tablesche } \\
\text { dule }\end{array}$ & Calculated & & & $\mathbf{2 1 2}$ & $\mathbf{1 9 0}$ \\
\hline Function & $\mathbf{9 6 . 1}$ & $\mathbf{0 . 0 7 9}$ & $\mathbf{1 8 9}$ & $\mathbf{2 0 . 1 5}$ & $\mathbf{2 0}$ \\
\hline
\end{tabular}

scale for middle school principals

This result can be explained by the fact that the difficult circumstances that the country went through and still stands made the Iraqi individual more able to assume many responsibilities and difficulties and face emotional situations, as well as his awareness of the presence of fierce attacks against his country and society, which increased his awareness and was born with him He defended the necessity of self-organization and managing it well, since the emotional organization of the self and managing its emotions helps the individual to get rid of negative feelings and helps him to drain the emotions in various ways, especially the headmaster of the school who the community holds responsible for caring for schools and their members, students, teachers and workers, it must be May be Of them in the emotional balance and the ability to control emotions.

4.1.2 The second objective: to identify the differences in the level of emotion management among middle school principals according to the gender variable (male, female).

To achieve this goal, the T-test was used for two independent samples, and the results were that the mean of the male sample scores was (193) and the standard deviation (12.8), while the mean of the female scores was equal to (216) and the standard deviation $(5,13)$ After using the $\mathrm{T}$ test for two 
independent samples, it was found that the calculated T value of (1.53) is smaller than the tabular T value of (1.96) at the level of significance (0.05) and degree of freedom (188), that is, there are differences in management Emotions according to the gender variable for school administrators and for females, and Table (4) shows the details.

Table (4) The $\mathrm{T}$ value of the significance of the difference in the agitation management, according to the type variable

\begin{tabular}{|c|c|c|c|c|c|c|c|}
\hline $\begin{array}{c}\text { Indication, } \\
\text { level }\end{array}$ & $\begin{array}{c}\text { Freedom } \\
\text { degree }\end{array}$ & $\begin{array}{c}\text { Table } \\
\mathrm{T} \\
\text { value }\end{array}$ & $\begin{array}{c}\text { Calculated } \\
\text { T value }\end{array}$ & $\begin{array}{c}\text { Standard } \\
\text { deviation }\end{array}$ & $\begin{array}{l}\text { Average } \\
\text { value }\end{array}$ & $\begin{array}{l}\text { The } \\
\text { number }\end{array}$ & Type \\
\hline 0,05 & 188 & 1,96 & 1,53 & 12,8 & 193 & 95 & Male \\
\cline { 5 - 8 } & & & $1,5,13$ & 216 & 95 & Female \\
\hline
\end{tabular}

From Table (4) it is clear that there are differences in the management of emotions according to the gender variable and in favor of females, and this result can be explained by the nature of Iraqi society, as women play multiple roles and perform various and multiple duties, such as working inside and outside the home and managing the responsibilities of the home and have a responsibility Educating children, all of which is born, increases the strength we carry for a woman and increases her patience, and thus forces her to manage her emotions in a large and appropriate way.

4.1.3 The third objective: to identify the differences in the level of emotion management among middle school principals according to the variable of years of service (one year - 5 years) and (5 or more).

To achieve this, the T-test was used for two independent samples, and the results were that the average score for the school principals sample whose service ranges between (one year - 5 years) has reached $(205)$ and the standard deviation $(12,15)$ while the mean for the degrees of the two Their service ranges (5 years - and above) equals (236) and the standard deviation (10,03). After using the $\mathrm{T}$ test for two independent samples, it was found that the calculated $\mathrm{T}$ value of $(2,81)$ is greater than the tabular $\mathrm{T}$ value of $(1,96)$ At the level of significance $(0.05)$ and degree of freedom (188), meaning that there are no differences in the management of emotions among principals of intermediate schools, according to Years of service varies, and table (5) shows details.

Table (5) T-value of the significance of the difference in running the emotions according to the variable for years of service

\begin{tabular}{|c|c|c|c|c|c|c|c|}
\hline $\begin{array}{c}\text { Indication, } \\
\text { level }\end{array}$ & $\begin{array}{c}\text { Freedom } \\
\text { degree }\end{array}$ & $\begin{array}{c}\text { Table } \\
\mathrm{T} \\
\text { value }\end{array}$ & $\begin{array}{c}\text { Calculated } \\
\text { T value }\end{array}$ & $\begin{array}{c}\text { Standard } \\
\text { deviation }\end{array}$ & $\begin{array}{c}\text { Average } \\
\text { arithmetic }\end{array}$ & $\begin{array}{c}\text { The } \\
\text { number }\end{array}$ & $\begin{array}{c}\text { Service } \\
\text { Year }\end{array}$ \\
\hline 0,05 & 188 & 1,96 & & 15,12 & 205 & 63 & $\begin{array}{c}1-5 \\
\text { Year }\end{array}$ \\
\cline { 5 - 8 } & & & 2,81 & 10,03 & 236 & 127 & $\begin{array}{c}5-\text { and } \\
\text { above } \\
\text { Year }\end{array}$ \\
\hline
\end{tabular}


This result can be explained by the fact that all members of Iraqi society are subjected to the same social conditions and psychological pressures in life and work, and therefore no differences appeared according to this variable.

\section{Summarized Conclusions and recommendations}

We are able to confirm the following conclusions:

1. The emotional management is self-managed and it leaks outward as a physiological reaction.

2. Positive thinking and behavior, such as managing emotions, may be caused by the pressures of life, or by a negative thing and an unfavorable circumstance for the individual and society.

And also the following recommendations:

3. Holding educational lectures and seminars by the directorates of education on how to increase the capacity of the school principal to manage his emotions, with the aim of overcoming the general and personal crises he is exposed to.

4. The responsible authorities in the directorates of education should assume the task of increasing the ability to manage emotions among male school principals.

\section{References}

1. John Mayer (1995), Emotional Intelligence, 2nd edition, by Leila Al-Jabali, Jordanian Book Center, Amman.

2. Khairi, Al-Maghazi Ajaj (2002), Emotional Intelligence, Theoretical Bases and Applications, Zahraa Publishing Library, Cairo.

3. Touqan Obeidat (1996), Scientific Research, its Tools and Methods, Dar Al-Fekr Publishing, Amman, Jordan.

4. Justice, Muhammad Mahmoud (1995), emotional equilibrium and its relationship to both cognitive speed and innovative thinking, Research Series, Journal of Educational Studies, Volume X, Part (77) Cairo, Egypt, p. 125.

5. Ghada Faisal (2012), emotion management and its relationship to some variables among female teachers of physical education and other subjects for secondary school.

6. Al-Musawi, Abdulaziz, and Sarah Thamer, emotional management among university students, the World Wide Web.

7. Baron, reuven (1998) Emotiona and Social Intelligence Linsights from the emotional quotient inventory in R.bar-on \& J.D Aparker (Eds) handbook of Emotional intelligece, san Francisco: jossy _Bass.

8. Berghaman, F (2001): Social Exclusion and the welfare state: An over view of conceptual issues and policy implication In social Exclusion and European policy, ed , D. Mayes, Berghaman, and R. 
9. Hein, Steve (2001) Emotional Intelligence: Stevehein@eqi.org, W.W.W.Cardboardkinky.net.

10. Lazarus, R. S. (1981): stress appraisal and coping New York.

11. Mayer,j: Salovey ,p; Caruso,d \& Sitarenios, G.(2001):Emotional Intelligence As a Standard Intelligence, San Francisco, American Psychological Association. Mayer,j: Salovey ,p; Caruso,d \& Sitarenios, G.(2001):Emotional Intelligence As a Standard Intelligence, San Francisco, American Psychological Association.

12. Mayer,j: Salovey ,p (2002) Emotional Intellignce Imagination ,cognition\& personality,Y.s.a

13. Tarannum, M and Khatoon, N. (2009): Self- Esteem and Emotional Stability of Visually Challenged Students, Journal of India Academy of Applied Psychology, 35(2). 